\title{
Review: Optimizing ruminant conversion of feed protein to human food protein
}

\author{
G. A. Broderick ${ }^{\dagger}$ \\ US Dairy Forage Research Center, University of Wisconsin and Broderick Nutrition \& Research, LLC, Madison, WI 53705 USA
}

(Received 12 March 2017; Accepted 11 August 2017; First published online 20 November 2017)

\begin{abstract}
Ruminant livestock have the ability to produce high-quality human food from feedstuffs of little or no value for humans. Balanced essential amino acid composition of meat and milk from ruminants makes those protein sources valuable adjuncts to human diets. It is anticipated that there will be increasing demand for ruminant proteins in the future. Increasing productivity per animal dilutes out the nutritional and environmental costs of maintenance and rearing dairy animals up to production. A number of nutritional strategies improve production per animal such as ration balancing in smallholder operations and small grain supplements to ruminants fed high-forage diets. Greenhouse gas emission intensity is reduced by increased productivity per animal; recent research has developed at least one effective inhibitor of methane production in the rumen. There is widespread over-feeding of protein to dairy cattle; milk and component yields can be maintained, and sometimes even increased, at lower protein intake. Group feeding dairy cows according to production and feeding diets higher in rumen-undegraded protein can improve milk and protein yield. Supplementing rumen-protected essential amino acids will also improve $N$ efficiency in some cases. Better $N$ utilization reduces urinary $N$, which is the most environmentally unstable form of excretory $N$. Employing nutritional models to more accurately meet animal requirements improves nutrient efficiency. Although smallholder enterprises, which are concentrated in tropical and semitropical regions of developing countries, are subject to different economic pressures, nutritional biology is similar at all production levels. Rather than milk volume, nutritional strategies should maximize milk component yield, which is proportional to market value as well as food value when milk nutrients are consumed directly by farmers and their families. Moving away from Holsteins toward smaller breeds such as Jerseys, Holstein-Jersey crosses or locally adapted breeds (e.g. Vechur) would also reduce lactose production and improve metabolic, environmental and economic efficiencies. Forages containing condensed tannins or polyphenol oxidase enzymes have reduced rumen protein degradation; ruminants capture this protein more efficiently for meat and milk. Although these forages generally have lower yields and persistence, genetic modification would allow insertion of these traits into more widely cultivated forages. Ruminants will retain their niches because of their ability to produce valuable human food from low value feedstuffs. Employing these emerging strategies will allow improved productive efficiency of ruminants in both developing and developed countries.
\end{abstract}

Keywords: ruminant, dairy, protein production, sustainability, greenhouse gases

\section{Implications}

Ruminants are important suppliers of high-quality protein because they utilize feed and by-products of little or no value for human food. Improved environmental and economic sustainability will derive from greater productivity per animal because this dilutes out fixed nutrient costs of maintenance and similar functions and reduces emission intensity of greenhouse gases (GHGs) per unit product. Applying strategies such as ration balancing and nutritional models, appropriate nutrient supplementation and using livestock

\footnotetext{
${ }^{\dagger}$ E-mail: gbroderi@wisc.edu
}

that better fit the 'market' (e.g. Jerseys and Vechur $v$. Holsteins) will make ruminant production more sustainable and ruminants will retain their niche for providing valuable human food.

\section{Introduction}

Humans have depended for millennia on ruminant animals, both wild and domestic, for high-quality protein. This is of course still the case, with meat and dairy products from ruminants representing major dietary protein sources in developed countries. It is anticipated that people in emerging nations will substantially increase their intake of animal 
protein in the future. There has, however, been a steady trend in the last few decades toward increasing consumption of poultry meat as a replacement for beef plus pork. In the United States, pork has held at between 20 and $25 \mathrm{~kg} /$ person per year, but beef consumption has fallen from $43 \mathrm{~kg}$ in 1975 to $24 \mathrm{~kg}$ per year in 2015; poultry meat has displayed a mirror-image response over the same time period, going from 21 to $48 \mathrm{~kg} / \mathrm{year}$, an increase of nearly $130 \%$ over this 40-year period (Figure 1; United States Department of Agriculture Economic Research Service (USDA ERS), 2017a). Similar trends are apparent in the EU From 1995 to 2009, consumption of poultry meat increased by $25 \%$, whereas beef consumption declined 9\% (Food and Agriculture Organization of the United Nations (FAO), 2015). These changes are driven by consumer economics: for example, the relative cost of poultry meat during the last 6 months of 2016 was $4.2 \mathrm{USD} / \mathrm{kg}$, whereas beef averaged $12.5 \mathrm{USD} / \mathrm{kg}$ during

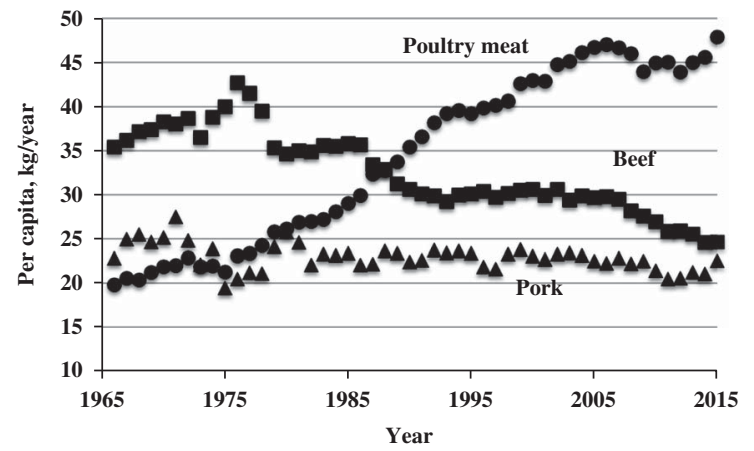

Figure 1 Per capita meat consumption in the United States (USDA ERS, 2017a). the same period (USDA ERS, 2017a). Although beef production is lower, energetic efficiency of poultry, swine and milk is similar; however, gross protein efficiency of poultry egg and meat production exceeds that of dairy and beef cattle and swine in converting dietary protein into food protein (Table 1; Council for Agricultural Science and Technology (CAST), 1999; Wilkinson, 2011). A more appropriate way to look at this conversion is to account for the proportion of feedstuffs for each production system deriving from potential human food. By this metric, beef and particularly dairy cattle are much more efficient in net production of human food protein. This is because both swine and poultry can consume dietary ingredients that can be eaten directly by humans. Of particular note are the data on Argentinian beef production: gross efficiency of converting dietary protein to meat protein is only 0.02 , but conversion of human-edible protein is 6.1 (Table 1); this high value derives from the fact that beef cattle consume only pasture and non-edible by-products in the Argentinian production system. Ruminants are major recyclers of by-products from food systems throughout the World. Oil-seed meals such as soybean meal and canola meal, which are produced during extraction of cooking oil, are major protein supplements fed to ruminants. One may argue about the wisdom of producing fuel ethanol from grains, but ruminants are the principal consumers of distillers grains co-products; the same is true for fermentation by-products deriving from production of alcohol consumed by humans. By-products from human food production such as crop residues, almond hulls, vegetable wastes, 'cookie dough' and a wide variety of materials represent major dietary ingredients wherever ruminants are fed.

Table 1 Animal systems: gross efficiencies of converting energy and protein into product and returns of human-edible inputs in product $^{1}$

\begin{tabular}{|c|c|c|c|c|c|}
\hline \multirow[b]{2}{*}{ Country } & \multirow[b]{2}{*}{ System } & \multicolumn{2}{|c|}{ Energy } & \multicolumn{2}{|c|}{ Protein } \\
\hline & & Gross efficiency & Human-edible return & Gross efficiency & Human-edible return \\
\hline \multirow[t]{5}{*}{ Argentina $^{2}$} & Poultry (eggs) & 0.17 & 0.26 & 0.23 & 0.45 \\
\hline & Poultry (meat) & 0.18 & 0.28 & 0.30 & 0.69 \\
\hline & Pork & 0.15 & 0.24 & 0.07 & 0.11 \\
\hline & Beef & 0.02 & 3.19 & 0.02 & 6.12 \\
\hline & Milk (cow) & 0.19 & 4.61 & 0.16 & 1.64 \\
\hline \multirow[t]{5}{*}{ United States ${ }^{2}$} & Poultry (eggs) & 0.17 & 0.24 & 0.24 & 0.36 \\
\hline & Poultry (meat) & 0.19 & 0.28 & 0.31 & 0.62 \\
\hline & Pork & 0.21 & 0.31 & 0.19 & 0.29 \\
\hline & Beef & 0.07 & 0.65 & 0.08 & 1.19 \\
\hline & Milk (cow) & 0.25 & 1.07 & 0.21 & 2.08 \\
\hline \multirow[t]{5}{*}{ United Kingdom ${ }^{3}$} & Poultry (eggs) & 0.20 & 0.28 & 0.31 & 0.43 \\
\hline & Poultry (meat) & 0.22 & 0.30 & 0.33 & 0.48 \\
\hline & Pork & 0.11 & 0.16 & 0.23 & 0.38 \\
\hline & Beef (mean) & 0.05 & 0.24 & 0.08 & 0.49 \\
\hline & Milk (cow) & 0.22 & 2.13 & 0.18 & 1.41 \\
\hline
\end{tabular}

${ }^{1}$ Gross efficiencies estimated as outputs of human-edible energy and protein divided by total energy and protein inputs. Human-edible returns calculated as human-edible outputs divided by human-edible inputs.

${ }^{2}$ Data summarized from CAST (1999).

${ }^{3}$ Data summarized from Wilkinson (2011). Values for 'Beef' are means of three production systems. 
Broderick

\section{Value of consuming high-quality ruminant proteins}

Human per capita protein consumption averages $77 \mathrm{~g} /$ day but the range is very wide - from $55 \mathrm{~g} /$ day in Sub-Saharan Africa to $103 \mathrm{~g} /$ day in the developed world (FAO, 2010). Even $55 \mathrm{~g} /$ day would be adequate if the protein had a good to excellent pattern of essential amino acids (EAA). The EAA are also referred to as indispensable amino acids - those nine protein amino acids that cannot be synthesized in the tissues but must be absorbed from the intestinal tract of all animals. Much of the food protein consumed in developing nations is of plant origin with less than optimal EAA composition. This point is illustrated by the data in Table 2, which compares protein quality of milk protein with that almond milk, a plant 'milk' the sales for which are growing rapidly in North America. As outlined by Professor Ertl at the Bristol meeting in January 2016, a comparison was made using the Digestible Indispensable Amino Acid Score (DIAAS) for evaluating the relative quality of food proteins (Ertl et al., 2016). This score relates a food's pattern of truly digested EAA to one of three standard FAO (2013a) patterns of required EAA. Data are available on true digestibility of individual EAA in milk but not almond milk; as recommended by FAO (2013b), the overall true digestibility for almond protein was applied to all EAA. The FAO EAA pattern for children aged 6 months to 3 years was used as the standard. Aside from the fact that almond milk provides only $1 \mathrm{~g}$ protein per serving $v .8 \mathrm{~g}$ for cow's milk, the DIAAS value of its protein is only 0.41 of the standard FAO pattern because of low lysine concentration. The DIAAS value of cow's milk is 1.12 based on its S-amino acid (methionine plus cystine) content. Hence, the protein in cow's milk has a relative DIAAS value $=100 \times 1.12 / 0.41=270 \%$ of the protein in almond milk. One must wonder at the growing popularity of almond milk.

Plant protein quality can be improved substantially by supplementation with ruminant proteins. The second comparison in Table 2 illustrates how complementary EAA patterns of animal and plant protein can be used to improve the value of the latter for human food. Peanuts (groundnuts) are relatively high in total protein and are widely consumed in both the developing and developed world. As is shown in Table 3, peanut protein is limiting in lysine, with 0.57 of the FAO standard for young growing children. However, a blend of milk and peanut proteins (two 'cups' of milk plus $150 \mathrm{~g}$ of peanuts) yields $53 \mathrm{~g}$ of protein that has 0.83 of the lysine concentration of the FAO standard. Thus, foods of ruminant origin provide proteins of excellent EAA composition with complementary EAA patterns.

\section{Improving productivity reduces environmental impact}

In recent years, livestock production systems have seen considerable improvement in output of product per unit feed input. Dijkstra et al. (2013) computed that, using the UK metabolizable energy system, energetic cost per kilogram of

Table 2 Comparison of the protein quality of almond milk and cow's milk using the Digestible Indispensable Amino Acid Score (DIAAS) method (Ertl et al., 2016)

\begin{tabular}{|c|c|c|c|c|c|c|c|}
\hline \multirow[b]{6}{*}{ Source } & \multirow[b]{6}{*}{ Item } & \multirow[b]{6}{*}{ Energy (Kcal) } & \multirow[b]{6}{*}{ Protein $(\mathrm{g})$} & \multicolumn{4}{|c|}{ FAO standard (6 months to 3 years) ${ }^{1}$} \\
\hline & & & & \multicolumn{4}{|c|}{ Indispensable amino acid (mg/g protein) } \\
\hline & & & & Lys & $\mathrm{SAA}^{2}$ & Thr & Trp \\
\hline & & & & 57 & 27 & 31 & 8.5 \\
\hline & & & & \multicolumn{4}{|c|}{ Indispensable amino acid (mg) } \\
\hline & & & & Lys & SAA & Thr & Trp \\
\hline \multirow[t]{5}{*}{ Almond milk (sweetened) } & Per serving $(240 \mathrm{~g})$ & 91 & 1.0 & 26.8 & 17.5 & 28.3 & 10.0 \\
\hline & $\mathrm{mg} / \mathrm{g}$ protein & & & 26.8 & 17.5 & 28.3 & 10.0 \\
\hline & True digestiblity $^{3}$ & & & 0.88 & 0.88 & 0.88 & 0.88 \\
\hline & DIAA $^{4}$ (mg/g protein) & & & 23.6 & 15.4 & 24.9 & 8.8 \\
\hline & DIAAS of almond milk & & & 0.41 & 0.57 & 0.80 & 1.04 \\
\hline \multirow[t]{5}{*}{ Cow's milk (1\% fat) } & Per serving $(244 \mathrm{~g})$ & 102 & 8.2 & 688 & 264 & 349 & 105 \\
\hline & $\mathrm{mg} / \mathrm{g}$ protein & & & 83.7 & 32.1 & 42.5 & 12.8 \\
\hline & True digestibility & & & 0.95 & 0.94 & 0.90 & 0.90 \\
\hline & DIAA (mg/g protein) & & & 79.5 & 30.2 & 38.2 & 11.5 \\
\hline & DIAAS of cow's milk & & & 1.39 & 1.12 & 1.23 & 1.35 \\
\hline Relative value & $1 \%$ Cow's milk/almond milk & & & $270 \%$ & & & \\
\hline
\end{tabular}

FAO = Food and Agriculture Organization of the United Nations.

${ }^{1}$ Standard pattern of require indispensable amino acids, expressed in mg amino acid/g protein consumed, for lysine (Lys), S-amino acids (SAA), threonine (Thr) and tryptophan (Trp) (FAO, 2013a).

${ }^{2} \mathrm{SAA}=$ methionine plus cystine.

${ }^{3}$ True digestibility of almond protein, mean of three cultivars from Ahrens et al. (2005).

${ }^{4}$ Digestible indispensable amino acids (DIAA) (true digestibility $\times$ amino acid concentration in protein). 
Table 3 Comparison of the protein quality of peanut (groundnut) protein alone and when supplemented with milk protein using the Digestible Indispensable Amino Acid Score (DIAAS) method (Ertl et al., 2016)

\begin{tabular}{|c|c|c|c|c|c|c|c|}
\hline \multirow[b]{6}{*}{ Source } & \multirow[b]{6}{*}{ Item } & \multirow[b]{6}{*}{ Energy (Kcal) } & \multirow[b]{6}{*}{ Protein $(\mathrm{g})$} & \multicolumn{4}{|c|}{ FAO standard (6 months to 3 years) ${ }^{1}$} \\
\hline & & & & \multicolumn{4}{|c|}{ Indispensable amino acid (mg/g protein) } \\
\hline & & & & Lys & SAA ${ }^{2}$ & Thr & Trp \\
\hline & & & & 57 & 27 & 31 & 8.5 \\
\hline & & & & \multicolumn{4}{|c|}{ Indispensable amino acid (mg) } \\
\hline & & & & Lys & SAA & Thr & Trp \\
\hline \multirow[t]{5}{*}{ Peanuts (oil-roasted) } & Per $100 \mathrm{~g}$ food & 525 & 24.4 & 876 & 613 & 836 & 237 \\
\hline & $\mathrm{mg} / \mathrm{g}$ protein & & & 35.9 & 25.1 & 34.2 & 9.7 \\
\hline & True digestiblity ${ }^{3}$ & & & 0.91 & 0.91 & 0.91 & 0.91 \\
\hline & $\mathrm{DIAA}^{4}$ (mg/g protein) & & & 32.7 & 22.9 & 31.2 & 8.9 \\
\hline & DIAAS of protein & & & 0.57 & 0.85 & 1.01 & 1.04 \\
\hline \multirow[t]{2}{*}{ Peanuts (oil-roasted) } & DIAA (mg/g protein) & & & 32.7 & 22.9 & 31.2 & 8.9 \\
\hline & DIAA (mg/150 g food) & & & 1196 & 836 & 1141 & 324 \\
\hline \multirow[t]{5}{*}{ Cow's milk (1\% fat) } & DIAA (mg/g protein) & & & 79.5 & 30.2 & 38.2 & 11.5 \\
\hline & DIAA (mg/488 $\mathrm{g}$ food) & & & 1307 & 496 & 628 & 189 \\
\hline & Totals & 992 & 53.0 & 2503 & 1333 & 1769 & 513 \\
\hline & DIAA (mg/g blend) & & & 47.2 & 25.1 & 33.3 & 9.7 \\
\hline & DIAAS of protein blend & & & 0.83 & 0.93 & 1.08 & 1.14 \\
\hline
\end{tabular}

FAO = Food and Agriculture Organization of the United Nations.

${ }^{1}$ Standard pattern of require indispensable amino acids, expressed in mg amino acid/g protein consumed, for lysine (Lys), S-amino acids (SAA), threonine (Thr) and tryptophan (Trp) (FAO, 2013a).

${ }^{2} \mathrm{SAA}=$ methionine plus cystine.

${ }^{3}$ True digestibility of peanut protein from Rutherfurd et al. (2015).

${ }^{4}$ Digestible indispensable amino acids (DIAA) (true digestibility $\times$ amino acid concentration in protein).

fat-corrected milk (FCM) and protein-corrected milk decreased 19\% when milk yield increased from 6000 to $10000 \mathrm{~kg} / \mathrm{cow}$ per year. Wilkinson and Garnsworthy (2017) showed that replacing dietary grazed grass or grass silage with corn silage at similar milk yield increased $\mathrm{N}$ efficiency and reduced the $C$ footprint. Similar reduction is also observed for metabolizable protein expenditures per kilogram of FCM and protein-corrected milk. These improvements result from dilution of nutrient costs for maintenance and other functions, such as those required for rearing the calf to first lactation and supporting the dry period. Dijkstra et al. (2013) also assessed human food energy and protein output per unit input of potential human food with differing number of lactations/cow. Efficiency increased substantially with increasing numbers of lactations/cow, maximizing at 3.5 lactations/cow; the US mean is 2.5 lactations/cow. Improved reproductive efficiency of lactating cows reduces the proportion of heifers that must be retained in the herd, as well as increases lactations/cow, thus improving efficiency of conversion of feed nutrients to milk (Garnsworthy, 2004). Greater animal productivity, more lactations per cow and improved reproductive efficiency are clearly effective means for diluting out the nutrient costs of ruminant food systems.

Methane production in the rumen represents an important loss of feed energy. Moreover, methane is a major GHG and domestic ruminants contribute an estimated $25 \%$ of total anthropogenic methane production (United States Environmental Protection Agency (US EPA), 2016). It can be argued that this is not a new phenomenon, because wild ruminants were major methane contributors in the past. For example, one estimate indicates that methane production from the wild ruminants (mostly bison) in the pre-settlement contiguous United States was $86 \%$ of the current magnitude from farmed ruminants in the same area (Hristov, 2012). Just as happens with gross energy and protein efficiencies, methane emission per unit product is also reduced with increasing productivity. It is estimated that the intensity of methane production declined from 31 in 1924 to $14 \mathrm{~g} / \mathrm{kg}$ milk in 2014 (US EPA, 2016). However, total GHG emissions (of which methane is a major part) plateau at about $2 \mathrm{~kg}$ $\mathrm{CO}_{2}$-equivalents $/ \mathrm{kg}$ fat and protein-corrected milk when yield reaches $4000 \mathrm{~kg} / \mathrm{year}$ of fat and protein-corrected milk, changing little at higher production (Gerber et al., 2011).

Reducing methane production in the rumen has been a much sought after goal for decades in ruminant nutrition. A number of compounds, for example, the ionophores monensin and lasalosid, have been found to reduce methanogenesis in short-term studies. The improvement in energetic efficiency obtained with feeding ionophores is widely believed to occur largely by suppressing methane formation. However, Guan et al. (2006) found that the depression of methanogenesis obtained with feeding cattle 
monensin alone or monensin plus lasalosid disappeared in 7 to 8 weeks. That these effects often do not persist is related to the thermodynamic advantage to methanogenic archaea of reducing carbon dioxide and other 1-carbon units with hydrogen; this results in rapid microbial adaptation such that methane production soon returns to pre-treatment levels (Patra et al., 2017); however, there is hope. Recent reports indicate that the inhibitor 3-nitrooxypropanol reduced methane production by more than $30 \%$, an effect that persisted for at least 12 weeks (Hristov et al., 2015). Moreover, certain dietary lipids such as medium-chain fatty acids and coconut oil also reduce methane production (Machmüller et al., 2001). These lipids act partly by suppressing rumen protozoa, thus also suppressing the methanogenic archaea that exist in close association with protozoa (Patra et al., 2017). One wonders whether the effects of lipids and 3-nitrooxypropanol would be additive, or even complementary, such that combining these materials might yield even greater reduction in rumen methanogenesis. Abecia et al. (2013) reported that reduced methane production persisted for at least 3 months after kids were treated with bromochloromethane, another methanogen inhibitor. Yanez-Ruiz et al. (2015) summarized literature suggesting that altering the rumen microbiome in early-life may reduce methane emissions in later life.

For a long time, livestock farmers believed that highprotein diets were more beneficial, increasing animal productivity. Dairy scientists have recently conducted several trials with the objective of assessing 'requirements' for dietary $\mathrm{CP}$ and found that producers were often over-feeding CP. Our own work showed that, with step-wise increases from $15.1 \%$ to $16.7 \%$ and $18.4 \%$ CP (achieved by adding solvent-extracted soybean meal to the diet at the expense of grain), milk and protein yield increased with the initial increment, but the second CP increment increased feed intake but with no effect on milk or protein yield (Broderick, 2003). The only result of increasing CP from $16.7 \%$ to $18.4 \%$ was increased excretion of environmentally unstable urinary $\mathrm{N}$; urinary $\mathrm{N}$ accounted for nearly all the additional $\mathrm{CP}$ equivalent. These three protein levels were each tested in diets containing three different concentrations of NDF. Although lower NDF (higher net energy) diets gave rise to greater milk yield, the relative response to dietary $C P$ was the same across all three energy levels. A number of other trials were also conducted around this same time addressing dietary CP concentration (added as soybean meal). Wattiaux and Karg (2004) found that increasing dietary CP from $16.5 \%$ to $17.9 \%$ did not improve yield of milk or milk components when diets contained $50 \%$ of dry matter (DM) as either alfalfa or corn silage. Olmos Colmenero and Broderick (2006) made step-wise increases of 1.5 percentage units, from $13.5 \%$ to $19.4 \% \mathrm{CP}$ and observed quadratic responses indicating that milk and protein yields maximized at $16.7 \%$ and $17.1 \% \mathrm{CP}$, respectively. In all three trials, rising milk urea $\mathrm{N}$ and urinary urea, and declining milk N/N intake, reflected the linear decline in $\mathrm{N}$ utilization with increasing $\mathrm{CP}$. That this information has been applied in practice is illustrated in Table 4. Keuning et al. (1999) surveyed the six Wisconsin
Table 4 Dietary CP contents and milk, fat and protein yields determined from surveying the Wisconsin dairy herds with highest rolling herd averages

\begin{tabular}{lcccc}
\hline \hline & \multicolumn{3}{c}{ Rolling herd averages $^{1}$} & \\
\cline { 2 - 4 } Year & Milk & $\begin{array}{c}\text { Milk fat } \\
(\mathrm{kg} / \text { lactation) }\end{array}$ & $\begin{array}{c}\text { Milk protein } \\
\text { (kg/lactation) }\end{array}$ & $\begin{array}{c}\text { Dietary CP } \\
\text { (\% of DM) }\end{array}$ \\
\hline $1998^{2}$ & 14200 & $505(3.55 \%)^{4}$ & $425(3.2 \%)^{3}$ & $19.4(18.5 \text { to } 21.5)^{5}$ \\
$2010^{6}$ & 15550 & $570(3.70 \%)^{4}$ & $470(3.0 \%)^{7}$ & $16.9(16.3 \text { to } 17.5)^{5}$
\end{tabular}

$\mathrm{DM}=$ Dry matter.

${ }^{1}$ Rolling herd averages reported to farmers by AgSource Dairy Herd Improvement Cooperative.

${ }^{2}$ Survey data on six herds reported by Keuning et al. (1999).

${ }^{3}$ Yield and mean milk concentration of milk total protein.

${ }^{4}$ Mean milk fat concentration.

${ }^{5}$ Range of dietary CP concentrations.

${ }^{6}$ Survey data on five herds reported by Shaver (2010).

${ }^{7}$ Yield and mean milk content of milk true protein.

dairy producers with the greatest rolling herd averages (milk/ 305-day lactation) and found that their lactating cows diets averaged $19.4 \%$ CP; indeed, one producer was feeding $21.5 \%$ dietary CP. A more recent survey (Shaver, 2010) showed an interesting trend: lactating cows in the five Wisconsin herds with the greatest milk yield/lactation were being fed diets averaging $16.9 \% \mathrm{CP}$, with the lowest herd receiving $16.3 \%$ dietary CP. Per lactation rolling herd averages actually increased $1350 \mathrm{~kg}$ milk, $65 \mathrm{~kg}$ fat and $45 \mathrm{~kg}$ true protein (Table 4). Indeed, Shaver (2010) reported that, in the period from 2004 to 2010, CP content of dairy rations declined by a mean 1.1 percentage units while milk and protein secretion rose, respectively, 1700 and $51 \mathrm{~kg} / \mathrm{lactation}$. Thus, not over-feeding dietary $\mathrm{CP}$ is an excellent means of improving $\mathrm{N}$ efficiency and reducing excretion of urinary $\mathrm{N}$, the most environmentally labile form of manure $\mathrm{N}$.

Kalscheur et al. (1999) found that reducing dietary CP from $17.4 \%$ to a mean $15.2 \%$ during weeks 4 to 14 of lactation reduced yields of milk and milk components. However, decreases from $15.3 \%$ to a mean $13.4 \%$ CP (weeks 19 to 29 of lactation) and from $14.2 \%$ to a mean $12.6 \%$ CP (weeks 24 to 34 of lactation) did not significantly reduce production of milk and milk components. The principal effect observed in the latter two phases of lactation with lower CP were improvements of 2 to 3 percentage units in apparent $\mathrm{N}$ efficiency. Wu and Satter (2000) divided the lactation curve into early lactation (weeks 1 to 16 after calving) and later lactation (weeks 17 to 44 after calving), and applied 4 different protein supplementation regimes over the whole lactation (Table 5). The dietary CP regime supporting optimum yield of $3.5 \%$ FCM with minimal manure $\mathrm{N}$ excretion over the whole lactation involved feeding $17.4 \%$ CP for the first 16-weeks after calving, followed by $16.0 \% \mathrm{CP}$ for the remaining 28 weeks. Increasing dietary $C P$ to as high as $19.3 \%$ during the first phase, or to $17.9 \% \mathrm{CP}$ during the second phase, did not improve FCM yield and only increased 
Table 5 Effect on yield of 3.5\% fat-corrected milk (FCM) and excretion of manure $\mathrm{N}$ of feeding dairy cows fed four different $\mathrm{CP}$ regimes during the first 16 weeks and last 28 weeks of 44-week lactations (Wu and Satter, 2000)

\begin{tabular}{|c|c|c|c|c|c|}
\hline \multirow[b]{2}{*}{ Protein regime } & \multicolumn{2}{|c|}{ Week of lactation } & \multirow[b]{2}{*}{$3.5 \%$ FCM } & \multirow[b]{2}{*}{ Manure N } & \multirow{2}{*}{$\begin{array}{l}\text { Manure } \\
\text { N/FCM }\end{array}$} \\
\hline & 1 to 16 & 17 to 44 & & & \\
\hline Low/low & 15.4 & 16.0 & $10691^{b}$ & $127^{c}$ & 0.0119 \\
\hline Mid/low & 17.4 & 16.0 & $11630^{\mathrm{a}}$ & $140^{\mathrm{b}}$ & 0.0120 \\
\hline $\mathrm{Mid} / \mathrm{mid}$ & 17.4 & 17.9 & $11802^{a}$ & $162^{a}$ & 0.0137 \\
\hline High/mid & 19.3 & 17.9 & $11557^{a}$ & $161^{\mathrm{a}}$ & 0.0139 \\
\hline
\end{tabular}

a,b,c Means in columns without common superscripts are different $(P<0.05)$.

manure $\mathrm{N}$ output. Reducing dietary CP intake in lactating cows substantially reduced volatile $\mathrm{N}$ losses from the stored manure (Külling et al., 2001). Partly as a convenience, dairy farmers often feed only a single ration to their lactating cows; because these diets are mainly designed for the animals with highest nutrient requirements, cows will be overfed CP for most of the lactation. In addition to reducing N excretion, group feeding cows to better match their nutrient requirements lowers feed costs and improves economic sustainability of dairy production. In their meta-analysis of North American and Northern European data on effects of varying dietary $\mathrm{CP}$ and energy content and intake on milk production and $\mathrm{N}$ utilization, Huhtanen and Hristov (2009) concluded that limiting CP intake was the most effective way to improve $\mathrm{N}$ efficiency. These workers also found that energy and $\mathrm{CP}$ intakes yielded the most reliable predictions of milk protein yield and $\mathrm{N}$ efficiency; adding rumen $\mathrm{CP}$ degradability (as predicted by National Research Council (NRC), 2001) reduced model precision. Sinclair et al. (2014) recently reviewed effects of dietary $\mathrm{CP}$ and energy intake in lactating cows and concluded that protein yield could be maintained at high $\mathrm{N}$ efficiencies.

\section{Protein quality is important to productive ruminants}

Until the mid-20th century, students of ruminant nutrition were taught that dietary protein quality was of no importance because microbial protein synthesis in the rumen met the animal's requirements for EAA. Indeed, there was clear evidence that rumen microbes utilized non-protein $\mathrm{N}$ sources such as urea to provide metabolizable EAA to the ruminant (e.g. Virtanen, 1966). However, a paradigm shift started in the early 1960 s with nutritionists recognizing the importance of EAA composition of ruminant diets. Large responses in wool growth were observed with abomasally infused protein and gram quantities of methionine and cystine (e.g. Reis and Schinckel, 1964). Substantial responses were later obtained with abomasal infusions of casein into lactating cows (e.g. Broderick et al., 1970), and abomasal infusions of casein and EAA mixtures into growing lambs (e.g. Schelling and Hatfield, 1968) and beef steers (Titgemeyer and Merchen, 1990). Since that era, a large body of literature has developed indicating that, particularly in very productive
Table 6 Response of lactating cows to supplementation of rumenundegraded protein (RUP) from solvent-extracted soybean meal (SSBM) or expeller soybean meal (ESBM) fed in supplement of alfalfa silage-based diets (Broderick et al., 1990) ${ }^{1}$

\begin{tabular}{lcccc}
\hline \hline & \multicolumn{4}{c}{ Supplemental protein source } \\
\cline { 2 - 5 } Items & Control & $0.6 \times$ SSBM & $0.6 \times$ ESBM & $1.0 \times$ SSBM \\
\hline Diet composition & & & & \\
SSBM (\% of DM) & 0 & 4.0 & 0 & 6.6 \\
ESBM (\% of DM) & 0 & 0 & 4.2 & 0 \\
CP (\% of DM) & 17.4 & 18.5 & 18.4 & 19.2 \\
Supplemental CP & 0 & 419 & 407 & 702 \\
$\quad$ (g/day) & & & & \\
RUP (g/day) & 0 & 126 & 273 & 210 \\
Production & & & & \\
Milk (kg/day) & 32.9 & 33.4 & 34.3 & 33.6 \\
Milk protein & 1.00 & 1.03 & 1.06 & 1.04 \\
$\quad$ (kg/day) & & & & \\
Milk fat (kg/day) & 1.18 & 1.20 & 1.22 & 1.20 \\
MUN (mM) & 4.7 & 5.6 & 5.3 & 6.2 \\
\hline \hline
\end{tabular}

$\mathrm{DM}=$ Dry matter; $\mathrm{MUN}=$ milk urea $\mathrm{N}$.

${ }^{1}$ Means from trials 1 and 2 (Broderick et al., 1990).

ruminants, microbial protein synthesis is not adequate to meet all of the animal's needs; these ruminants also required additional amounts of the EAA provided by dietary protein escaping the rumen (rumen-undegraded protein (RUP)). Supplementing RUP represents one way to reduce total CP intake, reducing the environmental footprint, without losing production. Typical results from dairy nutrition studies are presented in Table 6 (Broderick et al., 1990). Replacing conventional solvent-extracted soybean meal with expeller soybean meal, which is subjected to substantial heating during processing and has greater RUP content, increased production and reduced milk urea concentrations, an indicator of urinary $\mathrm{N}$ excretion (Nousiainen et al., 2004). Supplementation of about $400 \mathrm{~g}$ CP from expeller soybean meal actually provided more RUP, and supported numerically superior production, than supplementation with about $700 \mathrm{~g}$ CP from solvent-extracted soybean meal (Table 6). Brito and Broderick (2007) observed substantially greater milk and milk protein secretion when supplementing $16.5 \%$ CP diets with true proteins (soybean meal, cottonseed meal and canola meal) $v$. urea; moreover, yield of milk components was greatest among the true proteins when diets contained canola meal, least with cottonseed meal and intermediate with soybean meal. These differential responses occurred, despite the fact that the cottonseed meal diet supplied the greatest amount of RUP (Brito et al., 2007). The results were explained by the EAA composition of the RUP: although soybean meal is low in methionine, cottonseed meal is very low in lysine, and canola meal has a more balanced content of both methionine and lysine (NRC, 2001). Both a greater proportion RUP in its CP (Broderick et al., 2016), plus greater methionine in that RUP (NRC, 2001), explain the consistently greater milk protein yields observed when canola meal 
Table 7 Effect of supplementing a low CP diet with rumen-protected methionine, lysine and histidine on production and metabolism of lactating dairy cows (Lee et al., 2012)

\begin{tabular}{|c|c|c|c|c|c|}
\hline \multirow[b]{2}{*}{ Items } & \multicolumn{4}{|c|}{ Dietary metabolizable protein } & \multirow[b]{2}{*}{ Probability $^{3}$} \\
\hline & Adequate & Deficient & Deficient $+M L^{1}$ & Deficient $+\mathrm{MLH}^{2}$ & \\
\hline \multicolumn{6}{|l|}{ Diet } \\
\hline CP $(\%$ of DM) & 15.7 & 13.5 & 13.5 & 13.5 & - \\
\hline $\mathrm{MP}(\mathrm{NRC})^{4}(\mathrm{~kg} / \mathrm{day})$ & 2.66 & 2.08 & 2.15 & 2.20 & - \\
\hline \multicolumn{6}{|l|}{ Production } \\
\hline DM intake (kg/day) & 24.5 & 23.0 & 23.7 & 24.3 & 0.06 \\
\hline Milk (kg/day) & $38.8^{\mathrm{a}}$ & $35.2^{\mathrm{b}}$ & $36.9^{\mathrm{ab}}$ & $38.5^{\mathrm{a}}$ & $<0.01$ \\
\hline True protein (kg/day) & $1.13^{\mathrm{a}}$ & $1.01^{\mathrm{b}}$ & $1.10^{\mathrm{a}}$ & $1.14^{\mathrm{a}}$ & $<0.01$ \\
\hline Milk urea (mM) & $4.6^{\mathrm{a}}$ & $3.7^{\mathrm{bc}}$ & $3.6^{\mathrm{c}}$ & $4.0^{b}$ & $<0.01$ \\
\hline \multicolumn{6}{|l|}{ Metabolism } \\
\hline Urinary N (g/day) & $143^{a}$ & $92^{\mathrm{b}}$ & $87^{\mathrm{b}}$ & $97^{b}$ & $<0.01$ \\
\hline Total excreta N (g/day) & $376^{a}$ & $305^{\mathrm{b}}$ & $311^{\mathrm{b}}$ & $338^{\mathrm{ab}}$ & 0.01 \\
\hline NDF digestion (\%) & $42^{\mathrm{a}}$ & $38^{b}$ & $36^{\mathrm{b}}$ & $37^{b}$ & $<0.01$ \\
\hline $\mathrm{PBV}^{5}(\mathrm{~g} / \mathrm{kg} \mathrm{DM})$ & 0.4 & -7.8 & -9.0 & -9.7 & - \\
\hline $\begin{array}{l}\mathrm{DM}=\text { dry matter; NRC = Natic } \\
\mathrm{a}, \mathrm{b}, \mathrm{c} \text { Means in rows without co } \\
{ }^{1} \text { Supplemented with } 18 \text { and } 2 \\
{ }^{2} \text { Supplemented with } 18,24 \text { ar } \\
\text { 3Probability of a significant ef } \\
{ }^{4} \text { Metabolizable protein supply }\end{array}$ & $\begin{array}{l}\text { earch Coun } \\
\text { uperscripts } \\
\text { of rumen-p } \\
\text { day of rum } \\
\text { liet. } \\
\text { ted using t }\end{array}$ & $\begin{array}{l}\text { erent }(P<C \\
\text { d methionin } \\
\text { ected methi }\end{array}$ & $\begin{array}{l}\text { lysine (ML). } \\
\text { lysine and histidine }\end{array}$ & & \\
\hline
\end{tabular}

replaces soybean meal in the diet of lactating dairy cows (Huhtanen et al., 2011; Martineau et al., 2013).

Schwab et al. (1976) found that milk protein secretion increased $100 \mathrm{~g} /$ day with abomasal infusion of a mixture of nine EAA plus arginine in dairy cows fed a low CP basal diet; milk protein response to abomasal infusion of lysine plus methionine alone was only $40 \mathrm{~g} /$ day. Consistent observation of methionine and lysine as limiting EAA in abomasal infusion studies led eventually to development of rumenprotected methionine (RPM) and rumen-protected lysine (RPL). There have been consistent responses to RPM in dairy cattle on practical diets; the meta-analyses of Patton (2010) and Zanton et al. (2014) summarize most of this research. Somewhat less consistent responses to RPL have been obtained in dairy cattle (Vyas and Erdman, 2009). Rumen microbial protein has adequate levels of both lysine and methionine (NRC, 2001). However, RUP from soybean meal, the most common protein supplement, is high in lysine but relatively low in methionine (NRC, 2001), which probably explains these differential effects. Substantial milk protein responses to RPL are obtained when it supplements diets in which most or all of the RUP derives from grain sources such as corn distillers grains and corn gluten meal (e.g. Lobos et al., 2014). Rumen microbial protein is low in histidine relative to the EAA pattern of milk; Finnish workers detected histidine as first-limiting EAA when lactation diets were based on grass silage that contributed little RUP (Huhtanen et al., 2002). Lee et al. (2012) fed RPM, RPL plus their own preparation of rumen-protected histidine in low protein (13.5\% CP) diets and compared production to that on a $15.7 \%$ CP control diet (Table 7). These workers observed that milk and protein yield was only restored when all three rumen-protected EAA were supplemented. Addition of RPM and RPL increased blood methionine and lysine concentrations, but blood histidine remained very low until the rumenprotected histidine preparation was fed. Our excitement at the possibility of maintaining production while lowering urinary $\mathrm{N}$ excretion $32 \%$ on a $13.5 \%$ dietary $\mathrm{CP}$ is somewhat tempered by the apparent depression in NDF digestion in the rumen. Dietary CP not only supplies EAA via RUP, it also provides degraded CP that stimulates microbial fiber digestion in the rumen. A lack of degraded CP appears to have depressed fiber digestion.

\section{Research applicable to developing countries}

Much of the large body of literature on improving the environmental and economic sustainability of ruminant production derives from research conducted in developed countries, often under conditions of very high productivity. The amino acid composition of milk and tissue proteins is similar across mammalian species and ruminants depend on microbial protein to meet more than half of their requirements; thus, ruminants may be expected to respond similarly to improved supply of metabolizable protein and metabolizable amino acid at lower levels of production. This is illustrated by research results obtained in El Salvador by Corea et al. (2017). These workers tested feeding cowpea hay (Vigna sinensis), a legume that is relatively productive when grown under tropical conditions, as a replacement for onefourth of the commonly fed sorghum silage in the diet of crossbred dairy cows. As cowpea hay is substantially higher 
Table 8 Effect of dietary CP concentration and partial replacement of sorghum silage with cowpea (Vigna sinensis) hay on productivity and profitability of lactating dairy cows in El Salvador (Corea et al., 2017)

\begin{tabular}{|c|c|c|c|c|c|c|}
\hline \multirow{3}{*}{$\begin{array}{l}\text { Trait } \\
\text { Vigna ( } \% \text { of } D M)\end{array}$} & \multicolumn{4}{|c|}{ Dietary CP $(\%$ of DM) } & & \\
\hline & \multirow{2}{*}{$\frac{15.5}{0}$} & \multirow{2}{*}{$\begin{array}{c}15.5 \\
12.5\end{array}$} & \multirow{2}{*}{$\frac{17.0}{0}$} & \multirow{2}{*}{$\frac{17.0}{12.5}$} & \multicolumn{2}{|c|}{ Probability $^{1}$} \\
\hline & & & & & $\mathrm{CP}$ & Vigna \\
\hline DM intake (kg/day) & 19.6 & 19.6 & 20.5 & 19.6 & 0.14 & 0.12 \\
\hline Milk yield (kg/day) & 28.0 & 29.3 & 29.1 & 29.1 & 0.35 & 0.19 \\
\hline Milk/DM intake & 1.45 & 1.55 & 1.44 & 1.50 & 0.12 & $<0.01$ \\
\hline Fat yield (kg/day) & 0.96 & 0.99 & 0.98 & 1.02 & 0.38 & 0.17 \\
\hline $\begin{array}{l}\text { Protein yield } \\
\text { (kg/day) }\end{array}$ & 0.88 & 0.91 & 0.92 & 0.92 & 0.17 & 0.31 \\
\hline Milk urea $(\mathrm{mM})$ & 6.2 & 5.7 & 7.0 & 6.6 & $<0.01$ & $<0.01$ \\
\hline Milk N/N intake (\%) & 28.1 & 30.1 & 25.9 & 27.3 & $<0.01$ & $<0.01$ \\
\hline Urinary N (g/day) & 202 & 195 & 250 & 230 & $<0.01$ & 0.06 \\
\hline Fecal N (g/day) & 150 & 130 & 164 & 139 & $<0.01$ & $<0.01$ \\
\hline IOF (USD/cow) $)^{2}$ & $\$ 9.36$ & $\$ 10.50$ & $\$ 9.36$ & $\$ 10.22$ & 0.55 & $<0.01$ \\
\hline
\end{tabular}

$\mathrm{DM}=$ dry matter.

${ }^{1}$ Probability of orthogonal contrasts: $\mathrm{CP}=$ dietary $\mathrm{CP}$ concentration; Vigna = cowpea (Vigna sinensis) hay.

${ }^{2}$ Income over feed cost in US dollars.

in CP than sorghum, less soybean meal was required in the diet, lowering the ration cost. Replacing sorghum silage with cowpea hay resulted in increased milk/DM intake and milk N/N intake, lowered milk urea and urinary and fecal $\mathrm{N}$ excretion, and improved income over feed cost (Table 8). Moreover, the authors reported that increasing dietary CP by 1.5 percentage units only increased $\mathrm{N}$ excretion and feed cost without improving production.

Small amounts of grain supplementation often result in substantial improvements in productivity of ruminants on pasture or other high-forage regimes. One example is the response reported by Wales et al. (2009) to supplementing about 2.5 and $5.0 \mathrm{~kg} \mathrm{DM} /$ day of a carbohydrate mix to lactating cows grazing ryegrass pasture (Figure 2). Both levels of carbohydrate supplementation reduced pasture forage consumption but the first increment improved milk yield by $2.2 \mathrm{~kg} /$ day and $\mathrm{N}$ efficiency by about 3 percentage units. The second increment also improved $\mathrm{N}$ efficiency but had no further effect on milk yield. Milk protein yield increased by about $100 \mathrm{~g} /$ day with the first increment of carbohydrate supplementation, and milk protein content increased about 0.1 percentage unit with each increment of supplementation. This often observed response occurs because fermentable energy stimulates microbial protein formation in the rumen and metabolizable protein supply to the animal - the carbohydrate actually serves as a protein supplement. Earlier reports of this type of response in dairy cows fed alfalfa silage in confinement are those of Dhiman and Satter (1993), where corn silage supplementation stimulated milk and protein yield, and Ekinci and Broderick (1997), where grinding of high moisture corn reduced rumen ammonia and urinary $\mathrm{N}$ excretion and stimulated milk and protein yield. Sampath et al. (2008) obtained very similar responses when replacing about

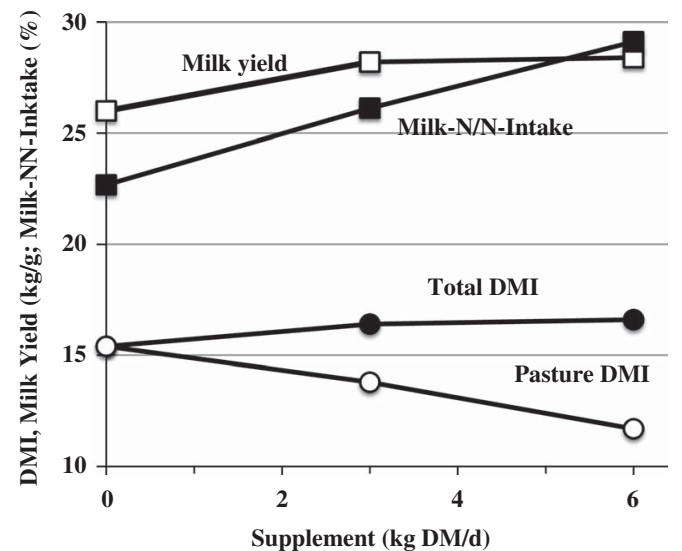

Figure 2 Effect on dry matter (DM) intake (DMI), milk yield and apparent $\mathrm{N}$ efficiency (milk N/N intake) of supplementing 2.5 and $5.0 \mathrm{~kg}$ $\mathrm{DM} /$ day from a carbohydrate mix to cows grazing perennial ryegrass in New Zealand (Wales et al., 2009). Supplement contained (DM basis) $65 \%$ barley, $30 \%$ steam-flaked maize, $5 \%$ molasses and $10 \%$ CP.

$1.5 \mathrm{~kg} /$ day of wheat bran with about $1.5 \mathrm{~kg} /$ day of maize (corn) grain in native Indian cattle fed largely on locally grown grass hay. This substitution did not increase feed costs, increased yield of milk and milk components and increased income over feed cost by 13 rupees/cow/day. All of these approaches for increasing diet fermentability increased both economic and environmental sustainability of dairy production.

Impressive results on reducing GHG emission intensity were obtained by Garg et al. (2016) when instituting an online ration balancing system for smallholder operations in four dairy regions of India (Table 9). Versus conventional nutrition and husbandry, life-cycle analysis was used to assess the effects of balancing rations from a large array of locally available feeds on GHG emissions from about 164000 each of dairy cows and buffalo. Based on these computations, ration balancing substantially improved yields of milk, fat and protein-corrected milk and reduced emission intensity (GHG/milk yield) by about one-third in both species. Note that methane and nitrous oxide production during lactation, and lifetime GHG equivalents from enteric methane, actually increased under the ration balancing regimes, but greater milk yields and much lower GHG contributions from unproductive animals improved emission intensity. Similar improvements in milk yields and in income with ration balancing were observed in smaller studies with indigenous dairy cows in Bangladesh (Kamal et al., 2009) and buffalo in a second Indian trial (Kumar et al., 2014). Clearly, strategic implementation of improved nutritional and management practices reduces the environmental footprint and improves the economic sustainability of ruminant production in smallholder dairy enterprises in developing countries.

\section{Using animals better adapted to local conditions}

Milk production in the Holstein Friesian breed has increased to truly impressive levels, with average yield per animal exceeding $15000 \mathrm{~kg} / \mathrm{lactation}$ in elite herds (e.g. Shaver, 2010). Production per cow in the overall US dairy herd, which 
Table 9 Effect of applying ration balancing to diets fed to 164000 cows and 164000 buffalo in four dairy production regions of India on estimated greenhouse gas (GHG) emissions and GHG emission intensity (Garg et al., 2016)

\begin{tabular}{|c|c|c|c|c|c|c|}
\hline \multirow[b]{2}{*}{ Items } & \multicolumn{2}{|c|}{ Cows } & \multirow[b]{2}{*}{ Probability } & \multicolumn{2}{|c|}{ Buffalo } & \multirow[b]{2}{*}{ Probability } \\
\hline & Before $\mathrm{RB}^{1}$ & After $\mathrm{RB}^{1}$ & & Before RB & After RB & \\
\hline \multicolumn{7}{|c|}{ Life stage $\mathrm{CH}_{4}$ emissions (kg/stage) } \\
\hline Heifer & 117 & 106 & * & 152 & 118 & * \\
\hline Lactation & 398 & 601 & * & 366 & 561 & * \\
\hline Dry period & 166 & 116 & * & 178 & 133 & * \\
\hline Unproductive $^{2}$ & 58 & 20 & * & 152 & 119 & * \\
\hline \multicolumn{7}{|c|}{ Life stage $\mathrm{N}_{2} \mathrm{O}$ emissions (kg/stage) } \\
\hline Heifer & 0.6 & 0.3 & * & 0.8 & 0.4 & * \\
\hline Lactation & 4.5 & 5.3 & * & 4.4 & 5.9 & * \\
\hline Dry period & 2.1 & 1.1 & * & 2.1 & 1.3 & * \\
\hline Unproductive & 0.6 & 0.1 & * & 1.6 & 1.1 & * \\
\hline \multicolumn{7}{|c|}{ Sources of lifetime GHG (MT CO 2 -eq) } \\
\hline $\mathrm{CH}_{4}$ (enteric) & 16.7 & 19.7 & * & 15.4 & 17.6 & * \\
\hline $\mathrm{CH}_{4}$ (manure) & 1.5 & 1.8 & * & 1.6 & 1.8 & * \\
\hline $\mathrm{N}_{2} \mathrm{O}$ (Manure) & 2.3 & 1.9 & * & 2.7 & 2.5 & * \\
\hline Feed GHG & 4.0 & 4.1 & Ns & 2.8 & 3.3 & * \\
\hline Total GHG emissions & 24.4 & 26.5 & $*$ & 22.4 & 25.1 & * \\
\hline Milk (MT) & 14.3 & 22.2 & * & 6.9 & 12.1 & * \\
\hline FPCM (MT) & 14.3 & 22.4 & * & 9.3 & 16.6 & * \\
\hline \multicolumn{7}{|c|}{ Emission intensity ( $\mathrm{kg} \mathrm{CO}_{2}$-eq/kg FPCM) } \\
\hline Overall mean & 1.7 & 1.2 & * & 2.4 & 1.5 & * \\
\hline
\end{tabular}

$\mathrm{MT}=$ metric tons; $\mathrm{CO}_{2}$-eq $=\mathrm{GHG}$ expressed in $\mathrm{CO}_{2}$-equivalents; $\mathrm{FPCM}=$ fat- and protein-corrected milk.

*Probability of significant effect of ration balancing programs $(P<0.05)$.

${ }^{1}$ Before and after application ration balancing (RB) programs available to farmers online.

${ }^{2}$ Unproductive animals are those that can no longer produce milk.

is more than $90 \%$ Holstein, exceeded $10000 \mathrm{~kg} / \mathrm{year}$ in 2014 (United States Department of Agriculture National Agricultural Statistics Service (USDA NASS), 2016). Although this level of production puts considerable stress on the animal, management has evolved such that these cows can be maintained in the resource rich environments available in North America and Europe. However, the market for dairy products has been shifting; much more milk equivalent is consumed as products such as cheese and much less as fluid milk. In the United States, per capita consumption of fluid milk has declined from $115 \mathrm{~kg} / \mathrm{year}$ in 1975 to $90 \mathrm{~kg} / \mathrm{year}$ in 2010 (USDA ERS, 2017b). In Wisconsin, about $90 \%$ of the 12.6 million metric tons of milk produced each year goes to cheese production and other non-fluid uses (USDA NASS, 2016). The $725 \mathrm{~kg}$ of lactose secreted in $15000 \mathrm{~kg}$ of milk is a relatively low value product that puts considerable metabolic stress on the cow. The value of milk as human food is mainly related to its protein concentration even when consumed on the farm as fluid milk. The higher protein and fat concentrations in Jersey milk fit more closely with a cheese market. Prendiville et al. (2009) compared whole-lactation data from Holstein, Jerseys and Holstein $\times$ Jersey crosses under Irish grazing management with limited grain supplementation. As expected, Holsteins secreted more milk than purebred Jerseys and Holstein-Jersey crosses. However, yield of fat plus protein per unit total DM intake of Jerseys and Holstein-Jersey crosses was $11 \%$ greater than for Holsteins; protein yields for Holstein, Jerseys and Holstein $\times$ Jersey crosses were, respectively, $0.39,0.37$ and $0.41 \mathrm{~kg} / \mathrm{day}$ in this study. Capper and Cady (2012) compared the environmental impact of the milk production from Jerseys $v$. Holsteins required to produce 500000 metric tons of cheese. The authors computed that 4.94 billion $\mathrm{kg}$ of Holstein milk v. 3.99 billion $\mathrm{kg}$ of Jersey milk would be needed. Note that, because of lower protein : fat ratio, 500000 metric tons of cheese made from Jersey milk would contain 148000 tons of protein and 192000 tons of fat $v .153000$ tons of protein and 188000 tons of fat if the cheese were made from Holstein milk. Lower yield per cow meant a greater Jersey population would be necessary; however, factors such as lower maintenance due to smaller body size reduced overall requirements for nutrients, land area and water for the Jersey breed. The $C$ footprint for producing the milk for 500000 metric tons of cheese was reduced by 1.66 metric tons of $\mathrm{CO}_{2}$-equivalents for Jerseys $v$. Holsteins.

There is renewed interest in smaller, native breeds such as Vechur cattle (Eisler et al., 2014). Such cattle produce much less milk and meat per animal but are better-adapted to the tropical and sub-tropical environments in the developing world. Many of the responses described above with improved nutrition and management were obtained using native breeds (Garg et al., 2016) or crosses between European breeds and native cattle (Corea et al., 2017). Another relatively new direction is the identification of, and selection for, dairy cattle with lower than average residual feed intakes (RFI); RFI values reflect the feed that goes for 
other than productive functions, such as maintenance and GHG emissions. Two recent reviews dealing with RFI and factors influencing RFI have been recently published (Waghorn and Hegarty, 2011; Vandehaar et al., 2016). Genetic selection for lower RFI will likely be a tool used for future improvements in sustainability of ruminant livestock production.

\section{Precision feeding of ruminant livestock}

Precision livestock farming is a relatively new approach to the very old idea of matching as precisely as possible production with procurement of the resources required for a livestock farming operation (Halachmi and Guarino, 2016). Interest is such that the journal Animal (no. 9, vol. 10, 2016) published a recent issue devoted solely to precision livestock farming. Precise feeding of a farm's livestock is an important component of precision livestock farming. Moreover, nutritional models are now widely applied to improve nutrient efficiency as well as profitability of dairy production (Feed into Milk, 2004; NorFor, 2011; INRA, Sauvant et al., 2015; NRC, White et al., 2017a and 2017b). Close attention to individual animals is, of course, possible on smallholder operations; applying the newly available ration balancing tools has led to the impressive improvements in GHG emission intensity described earlier. Tools are also available in developed countries for much greater precision of nutritional management. Robotic milking systems, plus automated measurement of rumen $\mathrm{pH}$, body core temperature and perhaps even feed intake, allow for collection of individual nutritional data. Heretofore, automated measurement of milk urea has not been available to farmers. The strong correlation of milk urea and $\mathrm{N}$ utilization efficiency would make timely milk urea data invaluable to dairy producers. For example, milking to milking changes in feed-group means for milk urea concentrations could be used to detect errors in ration formulation that require immediate correction, and would in this way improve nutrient efficiency.

\section{Improved crops for livestock production}

Certain plants contain compounds or enzyme systems that alter nutrient utilization, often improving productive efficiency and reducing environmental impact of ruminant production. In many areas of the world, forages are harvested as silages rather than hay because of greater speed of harvest and reduced risk of weather damage. However, during ensiling, usually more than half of the forage protein is broken down to amino acids and small peptides by enzymes released from cell rupture in the foliage. Red clover (Trifolium pratense) has a polyphenol oxidase (PPO) enzyme system that forms $o$-quinones from endogenous plant $o$-diphenols that react with foliage proteins to reduce their breakdown both in the silo (Lee et al., 2004; Fijałkowska et al., 2015) and the rumen (Broderick and Albrecht, 1997). As a result, rumen degradation of red clover protein is lower than is typical for most silages. For example, milk N/N intake was 2 to 4 percentage units higher in lactating cows fed red clover silage $v$. alfalfa silage in two trials (Broderick et al., 2001). Although DM intake was lower on red clover, milk yield/DM intake also was greater than on alfalfa silage. Marita et al. (2012) recently reported results from feeding silage mixtures produced from co-cultures of two grass species, one of which was high in PPO (orchard grass or cocksfoot, Dactylis glomerata) and the other of which (tall fescue, Festuca arundinacea) was high in chlorogenic acid, a substrate for PPO. Versus feeding silages made from the individual grass species, feeding silages made from the grass co-cultures more than doubled mean $\mathrm{N}$ retention in growing wether lambs.

It is well known that presence of condensed tannins in certain legume forages such as birdsfoot trefoil (Lotus corniculatus), sainfoin (Onobrychis viciifolia) and sulla (Hedysarum coronarium) result in reduced breakdown of their proteins in the silo (Dewhurst et al., 2009) and reduced degradation in the rumen (Broderick and Albrecht, 1997). Waghorn (2008) provided evidence that birdsfoot trefoil produces a type of condensed tannins in its foliage that is particularly effective for improving ruminant performance. We observed greater milk yield and $\mathrm{N}$ efficiency, and reduced milk urea and urinary $\mathrm{N}$ excretion, when replacing alfalfa silage with birdsfoot trefoil silage in three lactation studies (Hymes-Fecht et al., 2013; Broderick et al., 2017). Misselbrook et al. (2005) observed reduced losses of volatile $\mathrm{N}$ from the manure from the cows fed birdsfoot trefoil in the first of these trials. Similar effects have been observed with the condensed tannins in the foliage of leguminous trees grown in tropical agroforestry. Muinga et al. (1992) observed greater milk yield when supplementing crossbred cows with Leucaena leucocephala forage under tropical conditions. Although $L$. leucocephala has been widely adopted, this species is susceptible to attack by the insect Lucaena psyllid; Huang et al. (2010) reported that adding tannins extracted from a Leucaena hydrid resistant to this insect was more effective than $L$. leucocephala tannins in reducing both rumen protein degradation and methanogenesis. Archiméde et al. (2016) showed that replacing $44 \%$ of dietary DM from Dichanthium grass with one of three forage species containing condensed tannins increased dry matter intake (DMI) and depressed methane formation per unit DMI, without reducing total tract DM digestibility; the most effective forage species were $L$. leucocephala and Manihot esculenta, which contained the highest tannin concentrations. Lüscher et al. (2014) have recently reviewed many of the positive aspects, including reduced GHG footprint, of feeding forages containing condensed tannins to ruminants.

Production per unit area and persistency of red clover, birdsfoot trefoil and similar legume forages lag behind that of alfalfa. However, the agronomic characteristics of these forages might well be comparable with alfalfa had they received the same amount of plant breeding research. There have been recent, successful efforts at inserting the PPO enzyme system into alfalfa (Sullivan et al., 2008), although efforts continue to enable that plant to produce an 
endogenous source of $o$-diphenol substrate (Sullivan and Zeller, 2013). Genetic engineering is underway to extend condensed tannin expression from the seed coat to the herbage in alfalfa (Li et al., 2016). Although approaches of this type maybe unacceptable in other parts of the world, the Committee on Genetically Engineered Crops of the National Academy of Sciences of the United States (Gould et al., 2016) concluded that:

\begin{abstract}
... research that has been conducted in studies with animals and on chemical composition of GE [genetically engineered] foods reveals no differences that would implicate a higher risk to human health from eating GE foods than from eating their non-GE counterparts. Longterm epidemiological studies have not directly addressed GE food consumption, but available time-series epidemiological data do not show any disease or chronic conditions in populations that correlate with consumption of GE foods. The committee could not find persuasive evidence of adverse health effects directly attributable to consumption of GE foods.
\end{abstract}

\section{Summary and conclusions}

Ruminant livestock have the ability to produce high-quality human food, particularly high-quality protein, from feedstuffs of little or no value for human food and, thus, do not compete directly with the human population. Strategies that increase productivity per animal are effective for improving the sustainability of ruminant production by diluting out maintenance and other nutrient costs. Recent research indicates there is widespread over-feeding of protein to dairy cattle; milk and component yields can be maintained, and sometimes even increased, with reduced protein intake. Feeding proteins resistant to rumen microbial degradation and, in some cases rumen-protected EAA, elevate metabolizable protein and EAA supplies, further increasing performance and reducing environmental footprint. Evidence of this type has stimulated interest in precision feeding: using nutritional models to more accurately meet animal requirements. Ration balancing or feeding small supplements of readily fermented carbohydrate reduces urinary excretion of environmentally labile urea N. Modest grain supplements to grazing ruminants and those fed hay-crop silages improve $\mathrm{N}$ efficiency by stimulating microbial protein formation in the rumen. These strategies, plus newly developed methane inhibitors, indicate that significant reduction of enteric GHG is possible. The value of milk is directly related to its nutrient content whether milk is marketed or consumed on the farm as fluid milk; hence, nutritional strategies should maximize component yield rather than milk volume. Thus, moving away from Holsteins toward smaller breeds such as Jerseys, Holstein-Jersey crosses or locally adapted breeds (e.g. Vechur) would improve environmental and economic efficiency. Forages containing condensed tannins or PPOs have reduced rumen protein degradation; ruminants capture this protein more efficiently for meat and milk. Although these forages generally have low yields and persistence, genetic modification would allow insertion of these traits into more widely cultivated forages such as alfalfa and forage grasses. Ruminants will retain their niches because of their ability to produce valuable human food on low value feedstuffs. Emerging strategies of this type will allow improved productive efficiency of ruminants in both developing and developed countries.

\section{Acknowledgement}

This paper is an invited contribution following the First Global Farm Platform conference (12 to 15th January, 2016, Bristol, UK). The Global Farm Platform is an international initiative linking research farms around the globe to develop solutions for sustainable ruminant livestock production (www.globalfarmplatform.org).

\section{References}

Abecia L, Martín-García Al, Martínez G, Newbold CJ and Yáñez-Ruiz DR 2013. Nutritional intervention in early life to manipulate rumen microbial colonization and methane output by kid goats postweaning. Journal of Animal Science 91, 4832-4840.

Ahrens S, Venkatachalam M, Mistry AM, Lapsley K and Sathe SK 2005. Almond (Prunus dulcis L.) protein quality. Plant Foods for Human Nutrition 60, 123-128. Archimède $H$, Rira $M$, Barde DJ, Labirin F, Marie-Magdeleine $C$, Calif $B$, Periacarpin F, Fleury J, Rochette Y and Morgavi DP 2016. Potential of tannin-rich plants, Leucaena leucocephala, Glyricidia sepium and Manihot esculenta, to reduce enteric methane emissions in sheep. Journal of Animal Physiology and Animal Nutrition 100, 1149-1158.

Brito AF and Broderick GA 2007. Effects of different protein supplements on milk production and nutrient utilization in lactating dairy cows. Journal of Dairy Science 90, 1816-1827.

Brito AF, Broderick GA and Reynal SM 2007. Effects of different protein supplements on omasal nutrient flow and microbial protein synthesis in lactating dairy cows. Journal of Dairy Science 90, 1828-1841.

Broderick GA 2003. Effects of varying dietary protein and energy levels on the production of lactating dairy cows. Journal of Dairy Science 86, 1370-1381.

Broderick GA and Albrecht KA 1997. Ruminal in vitro degradation of protein in tanninfree and tannin-containing forage legume species. Crop Science 37, 1884-1891.

Broderick GA, Columbini S, Costa S, Karsli MA and Faciola AP 2016. Chemical and ruminal in vitro evaluation of Canadian canola meals produced over 4 years. Journal of Dairy Science 99, 7956-7970.

Broderick GA, Grabber JH, Muck RE and Hymes-Fecht UC 2017. Replacing alfalfa silage with tannin-containing birdsfoot trefoil silage in total mixed rations for lactating dairy cows. Journal of Dairy Science 100, 3548-3562.

Broderick GA, Kowalczyk T and Satter LD 1970. Milk production response to supplementation with encapsulated methionine per os or casein per abomasum. Journal of Dairy Science 53, 1714-1721.

Broderick GA, Ricker DB and Driver LS 1990. Expeller soybean meal and corn by-products versus solvent soybean meal for lactating dairy cows. Journal of Dairy Science 73, 453-462.

Broderick GA, Walgenbach RP and Maignan S 2001. Production of lactating dairy cows fed alfalfa or red clover silage at equal dry matter or crude protein contents in the diet. Journal of Dairy Science 84, 1728-1737.

Capper JL and Cady RA 2012. A comparison of the environmental impact of Jersey compared with Holstein milk for cheese production. Journal of Dairy Science 95, 165-176.

Corea EE, Aguilar JM, Alas NP, Alas EA, Flores JM and Broderick GA 2017. Effects of dietary cowpea (Vigna Sinensis) hay and protein level on milk yield milk composition, $\mathrm{N}$ efficiency and profitability of dairy cows. Animal Feed Science and Technology 226, 48-55.

Council for Agricultural Science and Technology (CAST) 1999. Animal agriculture and global food supply. Task Force Report No. 135, Council for Agricultural Science and Technology, Ames, IA, USA. 
Dewhurst RJ, Delaby L, Moloney A, Boland T and Lewis E 2009. Nutritive value of forage legumes used for grazing and silage. Irish Journal of Agricultural and Food Research 48, 167-187.

Dhiman TR and Satter LD 1993. Protein as the first-limiting nutrient for lactating dairy cows fed high proportions of good quality alfalfa silage. Journal of Dairy Science 76, 1960-1971.

Dijkstra J, France J, Ellis JL, Strathe AB, Kebreab E and Bannink A 2013. Production efficiency of ruminants: feed, nitrogen and methane. In Sustainable animal agriculture (ed. E Kebreab), pp. 10-25. CAB International, Boston, MA, USA

Eisler MC, Lee MRF, Tarlton JF, Martin GB, Beddington J, Dungait JAJ, Greathead H, Liu JX, Mathew S, Miller H, Misselbrook T, Murray P, Vinod VK, Van Saun R and Winter M 2014. Steps to sustainable livestock. Nature 507, 32-34.

Ekinci $C$ and Broderick GA 1997. Effect of processing high moisture ear corn on ruminal fermentation and milk yield. Journal of Dairy Science 80, 3298-3307.

Ertl P, Knaus W and Zollitsch W 2016. An approach to including protein quality when assessing the net contribution of livestock to human food supply. Animal 10, 1883-1889.

Feed into Milk 2004. Feed into Milk - a new applied feeding system for dairy cows: an advisor. Feed into Milk Consortium (ed. C Thomas), Nottingham University Press, Manor Farm, Church Lane, Thrumpton, Nottingham NG11 OAX, United Kingdom www.nup.com.

Food and Agriculture Organization of the United Nations (FAO) 2010. Daily protein intake per capita. FAO, Rome, Italy. Retrieved on 20 December 2016 from http://chartsbin.com/view/1155.

Food and Agriculture Organization of the United Nations (FAO) 2013a. Dietary protein quality evaluation in human nutrition. Food and Nutrition Paper No. 92. FAO, Rome, Italy.

Food and Agriculture Organization of the United Nations (FAO) 2013b. Environmental indicator report 2013. FAO, Rome, Italy. Retrieved on 10 July 2017 from https://www.eea.europa.eu/data-and-maps/daviz/per-capita-eu-27consumption-1\#tab-chart_1.

Food and Agriculture Organization of the United Nations (FAO) 2015. Per capita EU-27 consumption of meat, fish and dairy (by weight). Retrieved on 20 December 2016 from https://www.eea.europa.eu/data-and-maps/daviz/percapita-eu-27-consumption-1\#tab-chart_1.

Fijałkowska M, Pysera B, Lipiński K and Strusińska D 2015. Changes of nitrogen compounds during ensiling of high protein herbages - a review. Annuals of Animal Science 15, 289-305.

Garg MR, Sherasia PL, Phondba BT and Makkar HPS 2016. Greenhouse gas emission intensity based on lifetime milk production of dairy animals, as affected by ration-balancing program. Animal Production Science online early. Retrieved on 10 February 2017 from http://www.publish.csiro.au/an/Export Citation/AN15586.

Garnsworthy PC 2004. The environmental impact of fertility in dairy cows: a modelling approach to predict methane and ammonia emissions. Animal Feed Science and Technology 112, 211-223.

Gerber P, Vellinga T, Opio C and Steinfeld H 2011. Productivity gains and greenhouse gas emissions intensity in dairy systems. Livestock Science 139, 100-108.

Gould F, Amasino RM, Brossard D, Buell CR, Dixon RA, Falck-Zepeda JB, Gallo MA, Giller K, Glenna L, Griffin TS, Hamaker BR, Kareiva PM, Magraw D, Mallory-Smith C, Pixley K, Ransom EP, Rodemeyer M, Stelly DM, Stewart CN and Whitaker RJ 2016. Genetically engineered crops: experiences and prospects. National Academies Press, Washington, DC, USA.

Guan H, Wittenberg KM, Ominski KH and Krause DO 2006. Efficacy of ionophores in cattle diets for mitigation of enteric methane. Journal of Animal Science 84, 1896-1906.

Halachm I and Guarino M 2016. Editorial: precision livestock farming: a 'per animal' approach using advanced monitoring technologies. Animal 10, 1482-1483.

Hristov AN 2012. Historic, pre-European settlement, and present-day contribution of wild ruminants to enteric methane emissions in the United States. Journal of Animal Science 90, 1371-1375.

Hristov AN, Oh J, Giallongo F, Frederick TW, Harper MT, Weeks HL, Branco AF, Moate PJ, Deighton MH, Williams SRO, Kindermann M and Duval S 2015. An inhibitor persistently decreased enteric methane emission from dairy cows with no negative effect on milk production. Proceedings of the National Academy of Sciences 112, 10663-10668.
Huang XD, Liang JB, Tan HY, Yahya R, Khamseekhiew B and Ho YW 2010. Molecular weight and protein binding affinity of Leucaena condensed tannins and their effects on in vitro fermentation parameters. Animal Feed Science and Technology 159, 81-87.

Huhtanen P and Hristov AN 2009. A meta-analysis of the effects of dietary protein concentration and degradability on milk protein yield and milk $\mathrm{N}$ efficiency in dairy cows. Journal of Dairy Science 92, 3222-3232.

Huhtanen P, Hetta M and Swensson C 2011. Evaluation of canola meal as a protein supplement for dairy cows: a review and a meta-analysis. Canadian Journal of Animal Science 91, 529-543.

Huhtanen P, Vanhatalo A and Varvikko T 2002. Effects of abomasal infusions of histidine, glucose, and leucine on milk production and plasma metabolites of dairy cows fed grass silage diets. Journal of Dairy Science 85, 204-216.

Hymes-Fecht UC, Broderick GA, Muck RE and Grabber JH 2013. Replacing alfalfa or red clover silage with birdsfoot trefoil silage in total mixed rations increases production of lactating dairy cows. Journal of Dairy Science 96, 460-469.

Kalscheur KF, Vandersall JH, Erdman RA, Kohn RA and Russek-Cohen E 1999. Effects of dietary crude protein concentration and degradability on milk production responses of early, mid, and late lactation dairy cows. Journal of Dairy Science 82, 545-554.

Kamal MM, Iqbal DMH and Khaleduzzaman ABM 2009. Supplementation of maize-based concentrates and milk production in indigenous cows. The Bangladesh Veterinarian 26, 48-53.

Keuning JL, Gunderson SL and Shaver RD 1999. Survey of feeding and management practices on six high producing Wisconsin dairy herds. Journal of Dairy Science 82 (Midwest Abstracts suppl), 15 (Abstract 59). Retrieved on 15 January 2017 from https://www.adsa.org/Portals/0/SiteContent/docs/midwest/abstracts/ 1999-MW-abstracts.pdf.

Külling DR, Menzi H, Kröber TF, Nefte A, Sutter F, Lischer P and Kreuzer M 2001. Emissions of ammonia, nitrous oxide and methane from different types of dairy manure during storage as affected by dietary protein content. Journal of Agricultural Science 137, 235-250.

Kumar R, Nayak S, Baghel RPS and Khare A 2014. A strategic approach to improve production of buffaloes in rural areas in Central India through nutrient supplementation. Buffalo Bulletin 33, 485-493.

Lee C, Hristov AN, Cassidy TW, Heyler KS, Lapierre H, Varga GA, de Veth MJ, Patton RA and Parys C 2012. Rumen-protected lysine, methionine, and histidine increase milk protein yield in dairy cows fed a metabolizable proteindeficient diet. Journal of Dairy Science 95, 6042-6056.

Lee MRF, Winters AL, Scollan N, Dewhurst RJ, Theodorou MK and Minchin FR 2004. Plant-mediated lipolysis and proteolysis in red clover with different polyphenol oxidase activities. Journal of the Science of Food and Agriculture 84, 1639-1645.

Li P, Dong Q, Ge S, He X, Verdier J, Li D and Zhao J 2016. Metabolic engineering of proanthocyanidin production by repressing the isoflavone pathways and redirecting anthocyanidin precursor flux in legume. Plant Biotechnology Journal $14,1604-1618$

Lobos NE, Broderick GA and Wattiaux MA 2014. Effect of rumen-protected lysine supplementation of corn-protein based diets fed to lactating dairy cows. Journal of Dairy Science 97 (E-suppl. 1), 328 (Abstract).

Lüscher A, Mueller-Harvey I, Soussana JF, Rees RM and Peyraud JL 2014. Potential of legume-based grassland-livestock systems in Europe: a review. Grass and Forage Science 69, 206-228.

Machmüller A, Dohme F, Soliva CR, Wanner M and Kreuzer M 2001. Diet composition affects the level of ruminal methane suppression by medium-chain fatty acids. Australian Journal of Agricultural Research 52, 713-722.

Marita JM, Hatfield RD, Brink GE and Mertens DR 2012. Co-ensiling temperate grasses to improve protein use efficiency in ruminants. In Proceedings of the XVI International Silage Conference Hämeenlinna, Finland, 2-4 July 2012, pp. 132133. Retrieved on 1 February 2017 from https://portal.mtt.fi/portal/page/portal/ Artturi/artturi_web_service/xvi_international_silage_conference/ISC2012 Proceedings_5July2012.pdf.

Martineau R, Ouellet DR and Lapierre $H$ 2013. Feeding canola meal to dairy cows: a meta-analysis on lactational responses. Journal of Dairy Science 96, 1701-1714.

Misselbrook TH, Powell JM, Broderick GA and Grabber JH 2005. Dietary manipulation in dairy cattle: laboratory experiments to assess the influence on ammonia emissions. Journal of Dairy Science 88, 1765-1777.

Muinga RW, Thorpe W and Topps JH 1992. Voluntary food-intake, live-weight change and lactation performance of crossbred dairy-cows given ad-libitum 


\section{Broderick}

Pennisetum-Purpureum (Napier grass var. Bana) supplemented with Leucaena forage in the lowland semi-humid tropics. Animal Production 55, 331-337.

National Research Council (NRC) 2001. Nutrient requirements of dairy cattle, 7th revised edition. National Academy of Sciences, Washington, DC, USA.

NorFor 2011. NorFor - the Nordic feed evaluation system (ed. H Volden). EAAP Publication No. 130. Wageningen Academic Publishers, The Netherlands.

Nousiainen J, Shingfield KJ and Huhtanen P 2004. Evaluation of milk urea nitrogen as a diagnostic of protein feeding. Journal of Dairy Science 87, 386-398.

Olmos Colmenero JJ and Broderick GA 2006. Effect of dietary crude protein concentration on ruminal nitrogen metabolism in lactating dairy cows. Journal of Dairy Science 89, 1694-1703.

Patra A, Park T, Kim M and Yu Z 2017. Rumen methanogens and mitigation of methane emission by anti-methanogenic compounds and substances. Journal of Animal Science and Biotechnology 8, 13-30.

Patton RA 2010. Effect of rumen-protected methionine on feed intake, milk production, true milk protein concentration, and true milk protein yield, and the factors that influence these effects: a meta-analysis. Journal of Dairy Science 93, 2105-2118. Prendiville P, Pierce KM and Buckley F 2009. An evaluation of production efficiencies among lactating Holstein-Friesian, Jersey, and Jersey $\mathrm{x}$ Holstein-Friesian cows at pasture. Journal of Dairy Science 92, 6176-6185.

Reis PJ and Schinckel PG 1964. The growth and composition of wool. The effect of casein, gelatin and sulphur-containing amino acids given per abomasum. Australian Journal of Biological Science 17, 532-547.

Rutherfurd SM, Fanning AC, Miller BJ and Moughan PJ 2015. Scores and digestible indispensable amino acid scores differentially describe protein quality in growing male rats. Journal of Nutrition 145, 372-379.

Sampath KT, Chandrasekharaiah M and Praveen US 2008. Improving production performance of dairy animals in the villages by strategic supplementation - on farm trial. Indian Journal of Animal Sciences 78, 522-526.

Sauvant D, Cantalapiedra-Hijar G, Delaby L, Daniel B, Faverdin P and Nozière P 2015. Updating protein requirements in ruminants and determination of the responses of lactating females to metabolisable protein supply (English title). INRA Productions Animales 28, 347-367.

Schelling GT and Hatfield EE 1968. Effect of abomasally infused nitrogen sources on nitrogen retention of growing lambs. Journal of Nutrition 96, 319-326.

Schwab CG, Satter LD and Clay AB 1976. Responses of lactating dairy cows to abomasal infusions of amino acids. Journal of Dairy Science 59, 1254-1270.

Shaver RD 2010. Diets fed in selected WI high-producing dairy herds. Retrieved on 15 January 2017 from http://shaverlab.dysci.wisc.edu/wp-content/uploads/ sites/87/2015/04/2010wihigh-producingherds.pdf.

Sinclair KD, Garnsworthy PC, Mann GE and Sinclair LA 2014. Reducing dietary protein in dairy cow diets: implications for nitrogen utilization, milk production, welfare and fertility. Animal 8, 262-274.

Sullivan ML, Hatfield RD and Samac DA 2008. Cloning of an alfalfa polyphenol oxidase gene and evaluation of its potential in preventing postharvest protein degradation. Journal of the Science of Food and Agriculture 88, 1406-1414.

Sullivan ML and Zeller WE 2013. Efficacy of various naturally occurring caffeic acid derivatives in preventing post-harvest protein losses in forages. Journal of the Science of Food and Agriculture 93, 219-226.

Titgemeyer EC and Merchen NR 1990. The effect of abomasal methionine supplementation on nitrogen retention of growing steers postruminally infused with casein or nonsulfur-containing amino acids. Journal of Animal Science 68, 750-757.

United States Department of Agriculture Economic Research Service (USDA ERS) 2017a. Meat price spreads. Retrieved on 7 February 2017 from https://www.ers. usda.gov/data-products/meat-price-spreads/.
United States Department of Agriculture Economic Research Service (USDA ERS) 2017b. Fluid milk sales by product (Annual). Retrieved on 11 February 2017 from https://www.ers.usda.gov/data-products/dairy-data/.

United States Environmental Protection Agency (US EPA) 2016. Inventory of U.S. greenhouse gas emissions and sinks: 1990-2014. US EPA, Washington, DC, USA. Retrieved on 6 February 2017 from https://www.epa.gov/sites/production/ files/2016-04/documents/us-ghg-inventory-2016-main-text.pdf.

United States Department of Agriculture National Agricultural Statistics Service (USDA NASS) 2016. Milk production, disposition, and income 2015 summary. Retrieved on 11 February 2017 from https://www.ers.usda.gov/data-products/ dairy-datal.

VandeHaar MJ, Armentano LE, Weigel K, Spurlock DM, Tempelman RJ and Veerkamp R 2016. Harnessing the genetics of the modern dairy cow to continue improvements in feed efficiency. Journal of Dairy Science 99, 4941-4954.

Virtanen Al 1966. Milk production of cows on protein-free feed. Science 153 1603-1614.

Vyas D and Erdman RA 2009. Meta-analysis of milk protein yield responses to lysine and methionine supplementation. Journal of Dairy Science 92, 5011-5018.

Waghorn GC 2008. Beneficial and detrimental effects of dietary condensed tannins for sustainable sheep and goat production - progress and challenges. Animal Feed Science and Technology 147, 116-139.

Waghorn GC and Hegarty RS 2011. Lowering ruminant methane emissions through improved feed conversion efficiency. Animal Feed Science and Technology 166-167, 291-301.

Wales WJ, Kolver ES, Egan AR and Roche JR 2009. Effects of strain of HolsteinFriesian and concentrate supplementation on the fatty acid composition of milk fat of dairy cows grazing pasture in early lactation. Journal of Dairy Science 92, 247-255.

Wattiaux MA and Karg KL 2004. Protein level for alfalfa and corn silage-based diets: I. Lactational response and milk urea nitrogen. Journal of Dairy Science 87, 3480-3491.

White RR, Roman-Garcia Y, Firkins JL, Kononoff P, VandeHaar MJ, Tran H, McGill T, Garnett R and Hanigan MD 2017b. Evaluation of the National Research Council (2001) dairy model and derivation of new prediction equations. 2. Rumen degradable and undegradable protein. Journal of Dairy Science 100, 3611-3627.

White RR, Roman-Garcia Y, Firkins JL, VandeHaar MJ, Armentano LE, Weiss WP, McGill T, Garnett R and Hanigan MD 2017a. Evaluation of the National Research Council (2001) dairy model and derivation of new prediction equations. 1. Digestibility of fiber, fat, protein, and nonfiber carbohydrate. Journal of Dairy Science 100, 3591-3610.

Wilkinson JM 2011. Re-defining efficiency of feed use by livestock. Animal 5, 1014-1022.

Wilkinson JM and Garnsworthy PC 2017. Dietary options to reduce the environmental impact of milk production. Journal of Agricultural Science 155, 334-347.

Wu Z and Satter LD 2000. Milk production during the complete lactation of dairy cows fed diets containing different amounts of protein. Journal of Dairy Science 83, 1042-1051.

Yanez-Ruiz DR, Abecia L and Newbold CJ 2015. Manipulating rumen microbiome and fermentation through interventions during early life: a review. Frontiers in Microbiology 6, article no. 1133.

Zanton GI, Bowman GR, Vázquez-Añón M and Rode LM 2014. Meta-analysis of lactation performance in dairy cows receiving supplemental dietary methionine sources or postruminal infusion of methionine. Journal of Dairy Science 97, 7085-7101. 